\title{
EFFECTS OF Albizia saman PODS SUPPLEMENTATION ON FEED INTAKE AND LIVE WEIGHT CHANGES OF WHITE FULANI CALVES
}

\author{
B.A. ADEBIYI ${ }^{*}$ and J.A. ADENEYE \\ Department of Animal Science, \\ University of Ibadan, Ibadan \\ *Ogun State Agricultural Development Programme, Abeokuta Nigeria \\ Received 13 November 1998; Accepted 03 August 2000
}

\begin{abstract}
Nine weaned White Fulani Calves aged between 3-13 months, weighing between 28 $71 \mathrm{~kg}$ were fed on rations consisting of basal Guinea grass hay and $0,15,30 \%$ Albizia saman replacement for cassava waste in a concentrate ration as supplement in a $3 \times 3$ latin square design. With 3 replicate per ration and each period lasting 28 days feed intake and live weight changes of White Fulani Calves were determined. The DM intake increased with increased level of Albizia saman in the ration, the highest liveweight changes was recorded when the animals were fed $30 \%$ Albizia saman whole pod. The result showed that $A$ lbizia saman whole pod promotes intake and live weight changes of White Fulani calves, thus can be fed without any adverse effect on calves.
\end{abstract}

Keywords: Albizia saman Supple-mentation, feed intake, live weight changes, White Fulani, Calves.

\section{INTRODUCTION}

The increasing world population especially in Nigeria calls for an improvement in the method of livestock production. It is believed that one of the most serious problems and that which will be most difficult to solve in Nigeria and other African Countries is that of lack of dietary animal protein. This is due to the small size, slow rate of growth and poor productive and reproductive performance of livestock in this region.

Feed accounts for about $60-80 \%$ of the cost of raising animals, depending on species, breeds, and the environment (Jakonda, 1975). The productivity of ruminants is influenced by feed intake (Preston, 1986), the feed intake is however determined by both animal and feed factors. Akinnusi and Adeleye (1998) reported that supplementation increases feed intake, and liveweight gains in ruminants. Aina (1996) reported the best efficiency in goats when given supplement with their feed. The problem of scarcity of protein sources in ruminant nutrition is well known owing to the high cost of the conventional protein sources such as Palm Kernel Cake, (PKC) Groundnut Cake (GNC), Blood Meal (BM), Fish Meal (FM) and the competition for them by both monogastric and man. There is therefore the need to find alternative source of protem in ruminants nutrition.

Albizia or rain tree is a quick growing leguminous tree, it is adapted to a wide variety of soil types from alkaline to saline soil conditions (Prinsen, 1986). Its foliage is looped for fodder and also makes good green manure.

This study was therefore designed to determine the feed intake and weight changes of White Fulani Calves fed various combinations of cassava wastes and milled Albizia saman pods.

\section{MATERIALS AND METHODS}

Ripe Albizia saman pods were hand picked under rain tree plants within the University of Ibadan Campus. The pods were sundried for 34 days. The pods were ground into paste and the paste was autoclaved at $121^{\circ} \mathrm{C}$ and $151 \mathrm{~b}$ per sq. inch for $25 \mathrm{mins}$. The autoclaved Albiria was then sundried for about 2-3 days and stored in tightly fastened polythene storage bags and stored until required for mixing with other ingredients. Three experimental diets A, B and 
ADEBIYI and ADENEYE

TABLE 1: COMPOSITION OF THE EXPERIMENTAL CONCENTRATE DIETS

\begin{tabular}{llll}
\hline INGREDIENTS & \multicolumn{3}{c}{ TREATMENTS } \\
\hline & $\mathrm{A}(\%)$ & $\mathrm{B}(\%)$ & $\mathrm{C}(\%)$ \\
Albizia saman pod & 0.00 & 15.00 & 30.00 \\
Cassava Waste Meal & 98.00 & 83.00 & 68.00 \\
Oyster Shell & 1.00 & 1.00 & 1.00 \\
Nacl & 0.50 & 0.50 & 0.50 \\
Vit. Min. Mix & 0.50 & 0.50 & 0.50 \\
\hline
\end{tabular}

C were formulated to contain 0,15 and $30 \%$ milled Albizia saman pod (Table 1). The feeds were milled at the University of Ibadan Teaching and Research Farm's feedmill.

Nine weaned White-Fulani Calves aged between 3-13 months and weighing between $28-71 \mathrm{~kg}$ used in the study were selected from the Teaching and Research Farm of the University of Ibadan. The calves were housed in individual pen of $1.88 \times 0.98 \mathrm{~m}$ where concentrate diets, grass hay, fresh water and salt lick were supplied daily. They were allowed a week adjustment period before the start of experiment. Each animal was fed one of the three experimental diets in a $3 \times 3$ latin square design, they were fed 3 times daily $(07.00,13.00$ and 17.00 hours) with the supply of the concentrate diet first at the rate of $1.5 \%$ of the body weight, while the grass hay was supplied ad-libitum. Daily record of feed offered and left over by the individual animal were kept. Weekly live-weight and live-weight changes of the animal were also kept.

Thoroughly mixed representative samples of the forage, cassava wastes, Albizia saman pods and each of the 3 concentrate diets were taken for laboratory analysis. The various samples were milled and passed through a $2 \mathrm{~mm}$ mesh and analysed for proximate composition according to A.O.A.C (1975) procedures and NIF, ADF and Hemicellulose according to Van Soest method (1963) and Goering and Van Soest (1970).

Data were subjected to analysis of variance technique as applicable to latin square design (Steel and Torrie, 1980).

TABLE 2: CHEMICAL COMPOSITION OF BASAL GUINEA GRASS, GROUND Albizia saman WHOLE PODS AND EXPERIMENTAL CONCENTRATE DIETS (\% DM)

\begin{tabular}{|c|c|c|c|c|c|c|c|}
\hline COMPOSITION & $\begin{array}{l}\text { AUTO } \\
\text { CLAVED } \\
\text { ALBIZIA } \\
\end{array}$ & $\begin{array}{l}\text { UNAUTO } \\
\text { CLAVED } \\
\text { ALBIZIA } \\
\end{array}$ & $\begin{array}{l}\text { CASSAVA } \\
\text { WASTES }\end{array}$ & $\begin{array}{l}\text { GUNNEA } \\
\text { GRASS }\end{array}$ & A & $\mathrm{B}$ & $\mathrm{C}$ \\
\hline Dry Matter & 98.00 & 98.00 & 93.00 & 63.92 & 92.00 & 91.00 & 90.00 \\
\hline Crude Protein & 28.53 & 31.15 & 5.60 & 7.35 & 5.65 & 9.80 & 15.05 \\
\hline Ether Extract & 1.00 & 5.00 & 5.00 & 3.00 & 5.00 & 2.00 & 3.00 \\
\hline Ash & 10.00 & 10.00 & 9.00 & 9.70 & 10.00 & 9.00 & 10.00 \\
\hline Crude Fibre & 18.00 & 21.90 & 9.00 & 29.00 & 9.00 & 12.00 & 13.00 \\
\hline NDF & 33.38 & 26.56 & 20.51 & 81.74 & 20.51 & 21.71 & 55.96 \\
\hline ADF & 23.75 & 28.91 & 12.73 & 36.22 & 12.73 & 15.74 & 18.22 \\
\hline Hemicellulose & 52.57 & 42.18 & 74.54 & 27.56 & 74.54 & 68.52 & 63.56 \\
\hline NFE & 42.47 & 31.95 & 32.60 & 50.95 & 32.65 & 67.20 & 58.95 \\
\hline Nitrogen & 4.56 & 4.98 & 0.90 & 1.18 & 0.90 & 1.57 & 2.41 \\
\hline
\end{tabular}


RATION
A
B
$\mathrm{C}$

\begin{tabular}{llll}
\hline $\begin{array}{l}\text { HAY MEAN DM INTAKE } \\
\text { g/day }\end{array}$ & 133.6 .50 & 1346.33 & 1403.50 \\
g/100kg LW & 2412.89 & 2395.18 & 2508.50 \\
g/day/kgW & & 68.75 \\
CONCENTRATE & 66.48 & 66.22 & \\
$\begin{array}{l}\text { Mean DM intake } \\
\text { g/day }\end{array}$ & & & \\
g/100kg LW & & & 619.00 \\
g/day/kgW & 0.75 & 622.33 & 1106.34 \\
TOTAL DM INTAKE & 1134.99 & 1107.15 & 98.74 \\
g/day & 97.67 & 99.07 & 2022.50 \\
TOTAL N-INTAKE & 1965.17 & 1968.66 & \\
g/day & & & 31.48 \\
LIVE WEIGHT CHANGE & 21.43 & 25.66 & 141.67 \\
g/day & & & 14.28 \\
FEED CONVERSION RATIP & 20.25 & 48.81 & 22.68 \\
\hline
\end{tabular}

\section{RESULT AND DISCUSSION}

Table 2 shows the proximate composition of the basal guinea grass, ground Albizia saman whole pods and the experimental concentrate diets. From the table it could be seen that autoclaving reduced the crude fibre, ether extract, crude protein, acid detergent fibre and nitrogen content of Albizia but it increased the Nitrogen free extract, Neutral detergent Fibre and Hemicellulose.

The reduction in crude protein in the autoclaved Albizia agrees with the submission of Tagari et al. (1986) that heat treatment denatures protein in legumes. Table 3 shows that the DM intake from the grass hay increased from $1335.50-1403.50 \mathrm{~g} / \mathrm{day}$, with increase in the percentage of Albizia in the diet, when expressed on $100 \mathrm{~kg} \mathrm{L.W}$. the grass intake ranged between $2395-2508 \mathrm{~g} / 100 \mathrm{~kg}$ L.W. This agrees with the report of Akinnusi and Adeleye (1998) that the inclusion of concentrate in ruminant diets enhances feed intake. The Table also shows that $\mathrm{N}$-intake of the animals from grass also increased with an increase in the level of Albizia in the ration.

The live-weight changes reported in the study ranged between $48.41-141.67 \mathrm{~g} /$ day. This is however lower than between 33-42g/day reported by Krishna and Ranjhan (1982) for White Fulani Calves. The highest live weight change of $141.67 \mathrm{~g} /$ day was recorded when the calves were fed on $30 \%$ Albizia saman concentrate diet. The feed conversion ratios were shown in Table 3 to be $20,25,22.68$ and 14.28 for diets $A, B$ and $C$ respectively. The best efficiency of feed utilization was reported for the calves when they are fed on $30 \%$ Albizia saman concentrate ration. This agrees with the findings of Aina (1996) that the inclusion of concentrate in the ration of ruminant improves their efficiency of foed utilization. 


\section{ADEBIYI and ADENEYE}

\section{CONCLUSION}

It could be concluded that performance of White Fulani Calves fed Guinea grass could be enhanced with the inclusion of milled Albizia saman whole pods in their diet up to $30 \%$.

\section{REFERENCES}

AINA, A.B.J. (1996): Performance of fernale W.A.D. goats fed Spondias mombi plus concentrate. Nig. J. Anim. Prod. 23 (2) pp 161-163.

AKINNUSI, F.A.O and ADELEYE I.O.A. (1998): Response of West African Dwarf Ewes to pre-mating concentrate supplementation. Proceedings of $3^{\text {rd }}$ Aunual Conference of Animal Assoc. of Nig. Pp 126-127.

A.O.A.C. (1975): Official methods' of Analysis $12^{\text {th }}$ Fdition. Washington D.C. Assoc. of Official Analytical Chemist.

GOERING H.K. and VANSOEST P.J. (1970): Forage Fibre analysis (Apparatus, reagents, procedures and some applications). A.R.S. US. Dept. Agric. Hand book No. 379, Superitendent of Documents, U.S. Govt. printing office Washington D.C. 20402.

JAKONDA, S.Z. (1975): Improvement in livestock production, Nutrition and feeds. Nig. J. Anim. Prod. 2 (1) pp. 12.

KRISHNA, D.V. and RANJHAN, S.K. (1982): Growth, Nitrogen balance and
Nutritive intake in crossbred heifer calves fed different levels of energy and protein. The Ind. J. Anim. Sci. 52 (8) pp. 638-642. PRESTON, T.A. (1986): Validity of feeding standards and developing of feeding systems based on crop residues and Agroindustrial by-products. In Animal feeding (1) State of knowledge. Proceedings of A.A.O./LCA expert consultation. 5-7 March 1984. F.A.O. Anim. Prod. and Health. Paper No. 50. Rome 1986 pp. $197-$ 212.

PRINSEN, J.H. (1986): Potential of Albizia lebbeck (Mimosaceae) as a tropical fodder tree. - A review of literature. Trop. Grasslands 20 (2) pp. 78-83.

STEEL, R.G.D. and TORRIE, J.H. (1980): Principles and procedures of Statistics; $\mathrm{A} \mathrm{b}$ iometric approach. $2^{\text {nd }}$ Edition MC Graw Hill Book Co. Inc. New York.

TAGARI, H.G. PENA and SETTER L.D. (1986): Protein degradation by rumen microbes of heat treated whole Cotton Seeds. J. Anim. Sci. 62: pp. 1732-1736.

VAN SOEST, PJ. (1963): Use of detergents in the analysis of fibrous feeds II. A rapid method for determination of fibre and lignin. J. Assoc. Official Agric. Chem. 46 (5) 829 . 